2016, volume 5, issue 2

Ciukaj, R. (2016). Managing financial stability by the European Central Bank in the period 20082012. Copernican Journal of Finance \& Accounting, 5(2), 57-72. http://dx.doi.org/10.12775/ CJFA.2016.015

\author{
Radostaw Ciukaj* \\ Cracow University of Economics
}

\title{
MANAGING FINANCIAL STABILITY BY THE EUROPEAN CENTRAL BANK IN THE PERIOD 2008-2012
}

Keywords: unconventional monetary policy, quantitative easing, European Central Bank.

J E L Classification: E52, E58.

Abstract: In reaction to the global financial crisis and ineffectiveness of traditional monetary policy, European Central Bank undertook a number of unconventional measures to preserve financial stability in the EU. The paper presents a non-standard tools used by the ECB in the 2008-2012 period, as a response to shocks in the financial system and evaluates their effectiveness.

\section{INTRODUCTION}

Despite its importance and numerous discussions in the financial literature, the concept of financial stability has many definitions and manifestations. Moreover, the terms "financial stability" and "the stability of the financial system" are often used interchangeably in the financial literature. For the purpose of this article, the definition of financial stability used most frequently by the European Central Bank's (ECB) has been adopted, where financial stability is defined as: "a situation where the financial system is able to withstand eco-

Date of submission: January 9, 2017; date of acceptance: January 26, 2017.

* Contact information: radek.ciukaj@interia.pl, Nieciecza 45, 33-240 Żabno, Poland, phone: +48784680685 . 
nomic shocks without the occurrence of significant disturbances in the financial intermediation process and the overall availability of financial services" (EBC, 2016b).

The traditional approach of the central banks to achieve financial stability by maintaining low inflation and by providing a lender of last resort function, is obsolete in the light of the 2007-2009 crisis. Therefore, the aim of this paper is to analyze and to assess the anti-crisis tools, used by central banks during the last financial crisis to ensure the stability of the financial system, especially analyzing the unconventional measures used by the European Central Bank in the years 2008-2012. The first part of the article presents the tasks of the central bank in the financial safety net and traditional tools used by central banks to ensure financial stability, while the second part portrays the unconventional monetary policy instruments, which were used by ECB.

\section{THE RESEARCH METHODOLOGY AND THE COURSE OF THE RESEARCH PROCESS}

The preparation of the article included a thorough analysis of domestic and foreign literature regarding monetary policy, unconventional monetary policy tools and actions of the European Central Bank during the recent financial crisis. The information were also taken from official documents, published by selected international organizations and statistical data.

\section{THE ACTIVITIES OF CENTRAL BANKS TO ENSURE FINANCIAL STABILITY}

Axel A. Weber draws attention to the fact that, the role of central banks, as an entity acting for financial stability, should not lead to the conclusion that central banks have to take rapid action in the face of financial turmoil. The main entities, that should be responsible for financial stability, are primarily market participants and central banks play secondary role (BIS, 2008, p. 1).

Among the bodies of safety net, central banks have the longest history of activity for financial stability. Currently, as the functions of the central bank in the safety could be mentioned:

1) function as the lender of last resort,

2) function of taking care of the security of the payment system,

3) function of macro-prudential supervision,

4) function of an information policy of the central bank. 
The central bank, as a body in the safety net, is the lender of last resort. Emergency money supply conducted by central bank, in case of disorders associated with the lack of possibility to raise funds on the financial market, can be done in two ways, depending on the nature of the crisis:

1) through bilateral operations with a single bank if the only one institution, that is systemically important, has a trouble,

2) through open market operations, when the crisis is connected with increased demand for funds in the whole banking system (Szczepańska, 2007, p. 61).

The financial crisis 2007-2008 has confirmed the importance of the function of the central bank as a lender of last resort. Many banks launched this way of help for commercial banks in order to prevent the loss of their liquidity and thus avoid major turbulence in the financial system.

The payment system is a set of instruments, regulations, procedures, banking and inter-operating systems, which enable financial institutions for mutual presentation and exchange of data and documents related to the transfer of funds. It is also considered as a one of the most important elements of not only the infrastructure of financial markets, but also the entire economy. In the last decades turnovers in payment systems have significantly increased, what is more in some countries it exceeds the country's GDP. Therefore, the security of the payment system is essential for preserving the stability of the financial system. The tasks which are performed by central banks in connection to payment systems, are focused on two areas:

1) operational area,

2) regulatory and supervisory area.

The functions of the central bank in the operational area rely on the creation and operation of payment systems. The central bank as the operator and owner of the system has the opportunity to influence during the design and implementation of the system. In most countries, central banks own or run at least one payment system (especially high-value systems, which are used to implement monetary policy instruments).

The functions of the central bank in the regulatory and supervisory area focus mainly on the reduction of risk and the appropriate management of this risk by payment systems. At the same time the central banks must heed the efficiency of the payment system, because it is not advisable to create a completely secure system that on the other side would be too costly for users. Oversight of payment systems refers to a transfer of funds, and not to individual participants. 
Globalization, bigger and bigger rate of assets of the financial sector in relation to country's GDP and the growing relations of the financial system to the real economy have created the need to monitor the condition of the whole financial sector, instead of a single institution. These activities are called macroprudential analysis and naturally become the domain of central banks, because they have already been leading analysis for monetary policy purposes, have skilled staff, adequate knowledge and tools. Differences between macro and micro-prudential analysis presents Table 1.

Table 1. Differences between micro and macro-prudential approach to supervision

\begin{tabular}{|c|c|c|}
\hline \multirow{2}{*}{ Specification } & \multicolumn{2}{|c|}{ Method of analysis } \\
\hline & Micro-prudential & Macro-prudential \\
\hline Direct purpose & $\begin{array}{l}\text { limit risks to a single financial insti- } \\
\text { tution }\end{array}$ & $\begin{array}{l}\text { limit risks to the entire financial } \\
\text { system }\end{array}$ \\
\hline Final purpose & $\begin{array}{l}\text { protection of depositors and inves- } \\
\text { tors }\end{array}$ & $\begin{array}{l}\text { avoiding macroeconomic costs } \\
\text { of the crisis (fall in GDP) }\end{array}$ \\
\hline $\begin{array}{l}\text { Relationships and linkages between } \\
\text { financial institutions }\end{array}$ & irrelevant & relevant \\
\hline $\begin{array}{l}\text { The perspective of risk's assessment } \\
\text { to financial stability }\end{array}$ & $\begin{array}{l}\text { from the point of view on the risk } \\
\text { for a single institution: bottom-up } \\
\text { approach }\end{array}$ & $\begin{array}{l}\text { from the point of view on the risk } \\
\text { for the instability of the entire } \\
\text { system: top-down approach }\end{array}$ \\
\hline Subject of analysis & single institution - singular data & $\begin{array}{l}\text { the whole financial system- aggre- } \\
\text { gated data }\end{array}$ \\
\hline Time perspective of analysis & approach based on the past & approach oriented for the future \\
\hline
\end{tabular}

S o u r c e : Szczepańska, 2007, p. 61.

The central bank also uses information policy as a tool to support the stability of the financial system. Along with the increase in complexity of new financial instruments, information policy can be used as an element of public education. Imitating reports about inflation, central banks have begun to publish the so-called. reports on financial stability (from year to year the number of published reports increases). Reports about the stability of the financial system is one of the few central bank's ways to communicate with the environment. Other measures include:

1) speeches of representatives of the central bank,

2) press publication of the central bank, 
3) information published on the website of the central bank (Szczepańska, 2007, p. 71).

In a country where the central bank communicates with the environment, it is easier to manage inflation expectations, and thus maintains the planned level of inflation, which is important factor for stability of the financial system (Capiga, 2010, p. 71).

\section{Stabilizing aCtions of the European CEntral Bank DURing THE FIRST PHASE OF THE FINANCIAL CRISIS}

Despite the first signs of the upcoming crisis in 2008, the European Central Bank raised interest rates by 25 basis points. This step was explained by the President of the ECB as the necessity of taking care of the central bank's primary objective, which is to maintain price stability (ECB, 2008). The first time, when interest rates of the main refinancing operations were reduced about 325 basis points, was at the end of 2008. At that time, this reduction was historically the lowest. In 2011, ECB raised again interest rates, because authorities of European Central Bank wanted to anchor inflations expectations at the level consistent with its mail goal (ECB, 2011a), but then they again returned to reductions of interest rates to achieve bottom-most level of rates: 0,3 (rate of credit at the end of day), 0,05 (main refinancing operation rate) and minus 0,3 (deposit rate at the end of day) (ECB, 2016a). Chart 1 shows the fluctuations of ECB's interest rates between 2008 and 2015.

It is advisable to notice the fact, that initially ECB narrowed the spread between lending and deposit rates. This action was supposed to limit the variability of short-term rates, so between October 2008 and January 2009 the corridor was narrowed by 100 basis point. When financial markets calmed down slightly, ECB has attempted to extend the corridor to a limit of 200 basis points (Bogołębska, 2012, p. 56).

Despite the reduction of interest rated by European Central bank to historically lowest level, effectiveness of this tool was insufficient. ECB encountered three limitations on conducting traditional monetary policy:

1) it reached lower boundaries of the main interest rate, which caused it impossible to further cuts,

2) increased demand for financial reserves, which restricted redistribution of liquidity between financial institutions and reduced ECB's control over rates on money market, 
3) disturbance in functioning of transmission mechanism of monetary policy, what resulted in lower reactions of most segments of economy for monetary impulses, than it was expected (Janus, 2013, p. 1).

Chart 1. Fluctuations of ECB's interest rated between 2008 and 2015

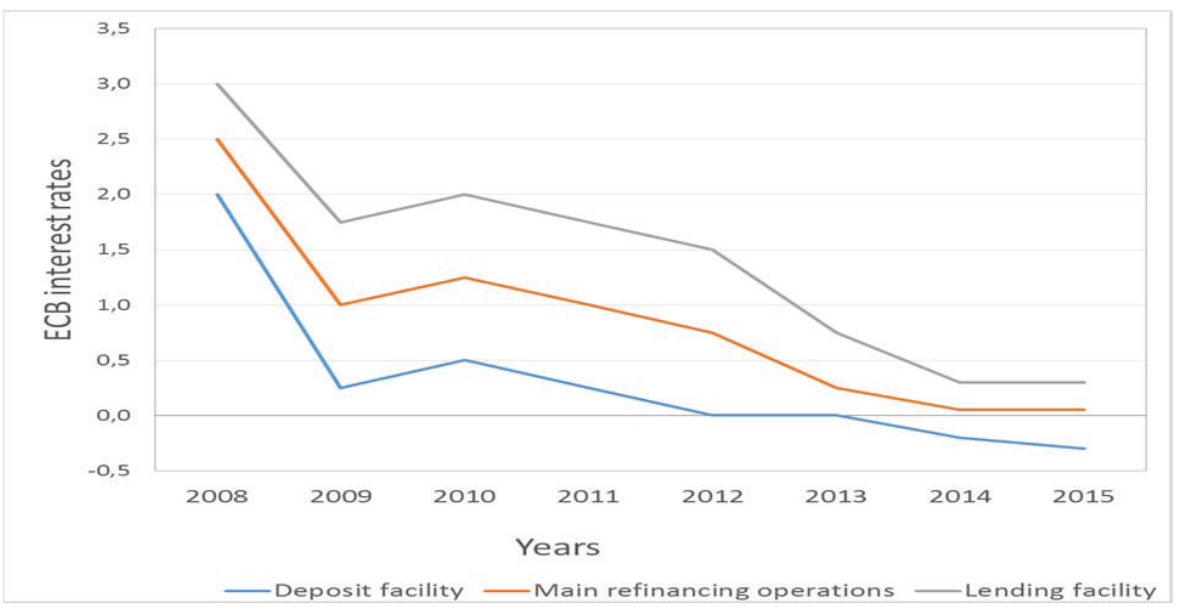

S o u r c e : based on: https://www.ecb.europa.eu/stats/monetary/rates/html/index.en.html.

In the face of inefficiency of monetary policy traditional instruments, European Central Bank had to reach for unconventional instruments. Their aim was to restore correct monetary policy transmission and to provide incentives to stimulate economy (Żywiecka, 2014, p. 73). These include:

1) forward guidance,

2) quantitative easing,

3) qualitative easing (Bernanke, Reinhart \& Sack, 2004, p. 3).

The first of these methods involves the use of communication policy for shaping public expectations about future course of interest rates. In other words, central bank communicates to the market about planned interest rates policy in a time horizon, longer than till next meeting of decision-making body. The main goal of this tool, during the last crisis, was to build society and institutions expectations about ECB' interest rate policy and thus affect the growth of investment and consumption and stimulate economic situation (NBP, 2013, p. 40). According to ECB, it can be distinguished 4 types of forward guidance: 
1) clean quality forward guidance - in this approach central bank indicates direction of future monetary policy, but does not specify limits or conditions, that must be met in order to change policy,

2) qualitative forward guidance - the possibility of changes in indicated direction of monetary policy, depends on the size of the descriptively expressed economic indicators,

3) based on the calendar forward guidance- central bank indicates date, since when specified monetary policy will be lead,

4) based on the results forward guidance - central bank determines the change of monetary policy of achieving numerical economic measures (Issing, 2014, p. 4).

Central bank must be sure about the present and the future economic situation, if it wants to apply forward guidance. The effectiveness of this tool depends on understanding of central bank's intentions, and if central bank has a public trust.

Quantitative easing is characterized by enlargement of monetary base above the level needed to achieve zero interest rates. As an example, we can indicate the purchase of bond by central bank with the help of newly issued funds. Such tool has effect of reducing long-term profitability of debt securities, and thus lower long-term interest rates (Pronobis, 2014, p. 17). Quantitative easing affects the market by omitting interest rate channel, but the tool has impact on market interest rates by "pumping" additional cash into market (Przybylska-Kapuścińska, 2012, p. 63).

Qualitative easing is also aimed at lowering long-term interest rates. However, in this case, central bank does not issue additional cash, named "great power money", and increase its balance sheet. Central bank exchanges simply owned assets into cash. As example might be sale of securities with shorter maturity date and buying of securities with longer maturity date. In other words, replacing more liquid securities for less liquid or buyinh more risky assets and selling less risky assets in the same time. Changes in demand for assets give rise to changes in their values, and thus changes in profitability. Qualitative easing changes profile and type of risk in the central bank's portfolio. Figure 1 shows the comparison between quantitative easing and qualitative easing. 
Figure 1. Comparison between quantitative easing and qualitative easing
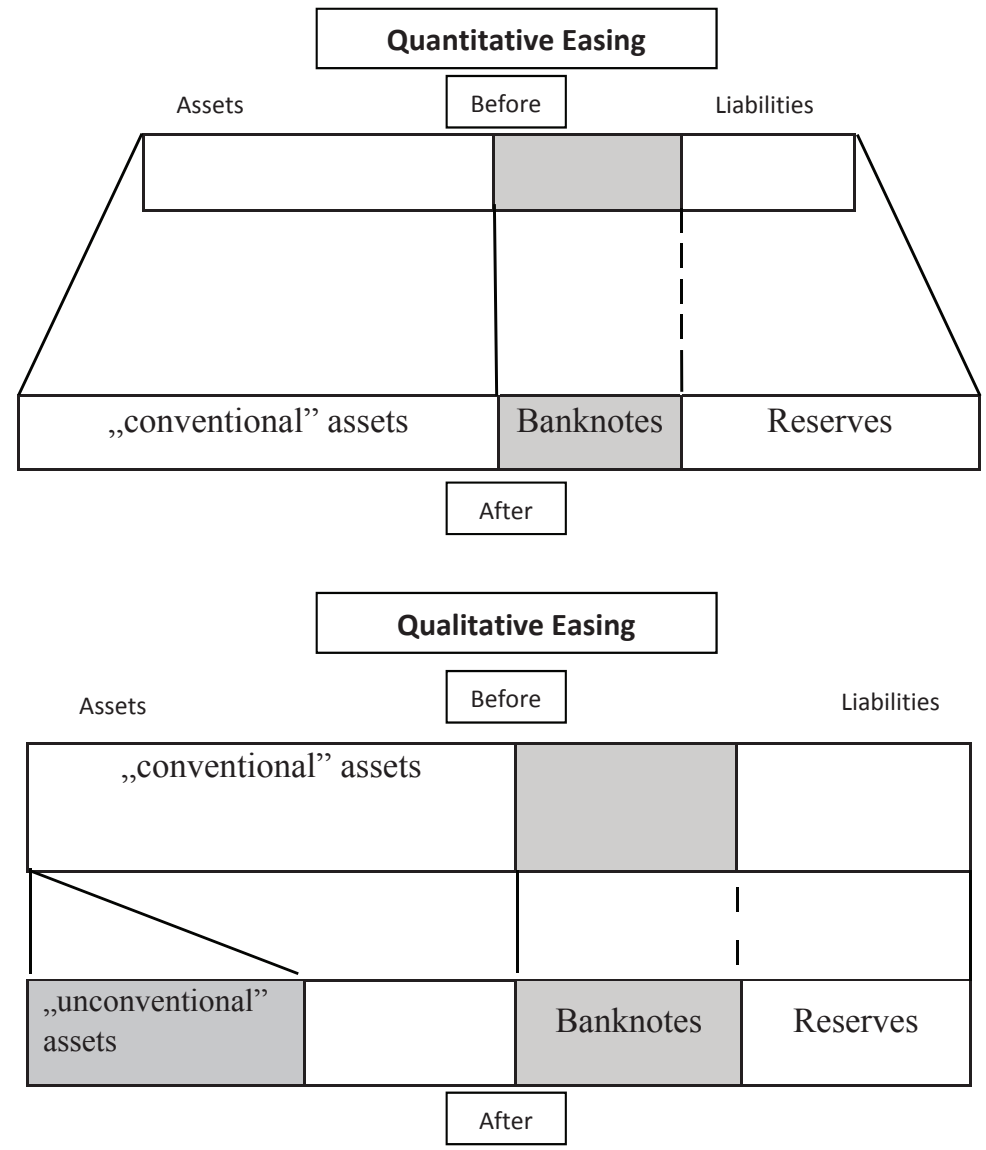

S o u r c e : Lenza, Pill, \& Reichlin, 2010, p. 10.

Division of unconventional monetary policy tool can take place also according to other criteria, which are presented in Table 2. 
Table 2. Division of unconventional monetary policy tools

\begin{tabular}{|l|l|}
\hline \hline \multicolumn{1}{|c|}{ Instrument } & \multicolumn{1}{|c|}{ Characteristics of instrument } \\
\hline Direct quantitative easing & $\begin{array}{l}\text { Central banks increase their balance sheet sums by buying all sorts of assets } \\
\text { from any market participants, but in practice they buy long-term govern- } \\
\text { ment securities from commercials banks. The purpose of these instrument } \\
\text { is to provide additional cash to private sector, however, decision, whether } \\
\text { these fund will be used for credit activity or remain as a liquidity buffer, } \\
\text { belongs to commercial banks. }\end{array}$ \\
\hline Direct credit easing & $\begin{array}{l}\text { Central banks recognize shortages of liquidity in specific market sectors } \\
\text { and reduce them by buying commercial papers, corporate bonds and asset- } \\
\text { backed securities. }\end{array}$ \\
\hline Indirect quantitative /credit easing & $\begin{array}{l}\text { Central bank provides loans to commercial banks for longer periods and at } \\
\text { non-standard conditions. These loans are usually secured by a wide range } \\
\text { of collaterals. }\end{array}$ \\
\hline \hline
\end{tabular}

S o u r c e : based on: Szunke, 2013, p. 3.

Unconventional monetary policy provides liquidity to the banking sector. It is used in order to exert influence on security prices and market conditions by selling central bank's assets or buying new ones. Therefore, it is also called "balance sheet policy".

The ways, that European Central Bank used to provide additional liquidity to the banking sector, were: modifications in terms of maturity of open market operations, unconventional long-term operations, extensions of securities, which were accepted as collateral, swap lines with other central banks and purchase of securitized papers or accept them as collateral (PrzybylskaKapuścińska, 2012, p. 64).

Given the tensions on the money market in the first half of 2008, European Central Bank decided to increase liquidity, allowing banks to earlier fulfill their obligations about reserve requirement, what banks preferred, because of uncertainty and decreasing turnover on the market. ECB reduced liquidity at the end of reserve maintenance period, which is the reason why total level of liquidity within planned period remained unchanged (Żywiecka, 2014, p. 154).

Another step designed to increase access to central bank's liquidity was introduction of additional long-term refinancing operations - 6 months instead of 3 months - and later with even longer maturity terms. With this step, average maturity of refinancing period increased, which led to greater access to long-term money. The aim was to encourage banks to give more loans to economy (Żywiecka, 2014, p. 155). 
The third method, which was used by ECB as the answer for turmoil in financial market, was provision of liquidity in foreign currencies to banks. Reduced availability of unsecured loans has forced from banks to use secured financing, among others in the form of currency swaps. However, the acquisition of other currencies (especially dollars) also became difficult. ECB reacted quickly to this situation and concluded swap line with Federal Reserve System in 2007. Thanks to this action commercial bank were supplied with dollar funding (Żywiecka, 2014, p. 154). Later, ECB also concluded swap lines with other central banks (for example wit central bank of: Denmark, Latvia, Hungary, Poland and Sweden), giving to those countries access to liquidity in euro.

Activities associated with quantitative easing were important tools, used by European Central Bank as solution for crisis turmoil. An example of this type of action was announced on 7. May, 2009 - Covered Bond Purchase Programme (CBPP). The program was carried out in three stages: between July 2009 and June 2010 (CBPP1), second between November 2011 and October 2012 (CBPP2) and third since October 2014 (Palace du Luxembourg, 2012a). European Central bank pledged the purchase of covered bonds, which were issued in the euro area. In the first edition, it was allocated 60 billion euro for this purpose, while the requirement of issue amount was 500 million euro. Bonds had to have ranking at minimum AA level and maturity date should have been between 3 and 10 years (Żywiecka, 2014, p. 162). In the second edition, it was allocated 40 billion euro for this purpose and the minimum amount of issue was 300 million euro, while maturity date was changed for 10,5 years. Rating assigned to assets was downgraded to BBB- level (ECB, 2011b). In 2014, ECB announced third edition of CBPP program, but a lot of characteristics were modified. This time the program did not have specific ending date (expected period is two years), maturity date, minimum issue amount and size of planned purchase amount. Minimum rating was set at BBB- level (ECB, 2014). Details and comparison of CBPP programs are presented in Table 3.

Table 3. Covered Bond Purchase Programs

\begin{tabular}{|l|l|l|l|}
\hline \hline \multicolumn{1}{|c|}{ Stage of program } & \multicolumn{1}{|c|}{ CBPP1 } & \multicolumn{1}{c|}{ CBPP2 } & \multicolumn{1}{c|}{ CBPP3 } \\
\hline \hline Start date & July 2009 & November 2011 & October 2014 \\
\hline End date & June 2010 & October 2012 & - \\
\hline Duration & 12 months & 12 months & minimum 2 years \\
\hline
\end{tabular}


Table 3. Covered Bond Purchase Programs

\begin{tabular}{|l|l|l|l|}
\hline \multicolumn{1}{|c|}{ Stage of program } & \multicolumn{1}{c|}{ CBPP1 } & \multicolumn{1}{c|}{ CBPP2 } & \multicolumn{1}{c|}{ CBPP3 } \\
\hline \hline Maturity of bonds & $3-10$ years & $<=10,5$ years & no limit \\
\hline Minimum rating & AA & BBB- & BBB- \\
\hline $\begin{array}{l}\text { Minimum quantity of } \\
\text { emission }\end{array}$ & 500 million euro & 300 million euro & no limit \\
\hline Amount of purchase & 60 billion euro & 40 billion euro & no limit \\
\hline \hline
\end{tabular}

S o u r c e : based on: Żywiecka, 2014, p. 162, 167.

Market segment of covered bonds is valuable source of long-term capital for banks, which is used to finance fixed rate mortgages. Therefore, ECB's decision to buy bonds was dictated by a great need to provide liquidity to commercial banks in euro area (Żywiecka, 2014, p. 161).

\section{Stabilizing actions of the European Central Bank DURING THE SECOND PHASE OF THE FINANCIAL CRISIS}

The next phase of the crisis was associated with alarming fiscal situation and worse ratings of some countries from euro area. This situation was caused by: high public costs (incurred in order to rescue financial institutions), structural differences between countries the north and the south of Europe and growth in unfavorable relation of public debt to GDP of some countries. This was reflected in large difference between interest rated on treasury bonds od such countries as Greece, Italy and Spain, which stood on the edge of bankruptcy and German interest rates of government bonds. Help for endangered countries was assured by European Central Bank. It introduced another unconventional program - Securities Market Programme (SMP) (Żywiecka, 2014, p. 163). It has been implemented in May 2010 and had also two stages: between May and July 2010 and between August 2011 and January 2012. European Central Bank used this program to:

1) purchase debt securities, issued by government or public entities on the secondary market,

2) purchase debt securities, issued by private companied in the primary or the secondary market (Palace du Luxembourg, 2012b). 
ECB's main goal of this program was to maintain liquidity in the European debt security market, thus ensuring appropriate conditions for effective monetary policy (Żywiecka, 2014, p. 166).

Long Term Refinancing Operations (LTRO) should also have helped in strengthening the liquidity position of commercial banks. These are instruments, whose task is to provide additional funds to commercial banks for longer period than in the basic open market operations. Until the outbreak of the crisis, they had three month maturity period, later it was extended to six months and at the end to one year maturity period. In 2011, a spectacular step of ECB was the announcement the longest two refinancing operations, with maturity period of three years. There was also possibility of earlier repayment. In December 2011, RCB made its first bid for loans with value of 489,2 billion euro. 523 institutions responded to this offer. The second stage took place in February 2012. ECB offered 529,5 billion euro amount of money and 800 institutions answered to this offer (ECB, 2012). Details of LTROs have been presented in Table 4.

Table 4. Details of LTRO programs

\begin{tabular}{|l|l|l|}
\hline \hline \multicolumn{1}{|c|}{ Stage of program } & \multicolumn{1}{|c|}{ LTRO1 } & \multicolumn{1}{c|}{ LTRO2 } \\
\hline \hline Start date & December 2011 & February 2012 \\
\hline Value of granted loans & 489,2 billion euro & 529,5 billion euro \\
\hline Number of partners & 523 & 800 \\
\hline \hline
\end{tabular}

S o u r c e : based on: http://www.ecb.europa.eu/pub/pdf/other/mb201201_focus04.en.pdf.

In the second half of September 2012, financial markets were still characterized by various level of liquidity and profitability of bonds. Investors also showed aversion to own government bonds of some European countries in its portfolios. There were concerns about resignation of some countries from participating in euro area. Therefore, ECB announced further program to buy government bonds. Its name is Outright Monetary Transactions (OMT). Overriding aim was to assure the proper functioning of monetary policy transmission mechanism and to maintain uniformity of monetary policy. According to this program, undertaken actions consisted of unlimited buying of government bonds on the secondary market with maturity periods from 1 to 3 years. However, the bonds of country could be treated as a subject of transactions, if country: 
1) declared willingness to implement structural reforms and deficit reductions,

2) participates in one of recue programs in euro area: European Financial Stability Facility or European Stability Mechanism.

OMT, differently from the previous bond purchase programs, contained built-in mechanism to encourage countries to implementation of necessary reforms.

\section{Conclusions}

Radical steps were the answer of European Central Bank to shocks in the financial system, which were formed as a result of crisis 2007-2009. Main goal was to restore the balance in the financial system. These actions were difficult because of poor condition of the European economy, occurrence of debt crisis or possibility of disintegration of the euro area. Initial lowering of interest rates to historically low levels, did not brought the expected results. Limitations encountered by European Central Bank set him a new challenge, which was the use of unconventional monetary policy tools. They were complementary to the traditional interest rate policy. By using them, president of ECB had in mind five principles:

1) designing and implementing of unconventional instruments was supposed to serve a fundamental objective of ECB,

2) the purpose of these tools was removal of major obstacles, that interfere with proper transmission of monetary policy impulses,

3) unconventional programs were carried out with the tools, that were at the disposal of ECB,

4) unconventional instruments were implemented for certain period of time,

5) by using unconventional tools, whole institutional environment hat to strive to reactivate private markets (Żywiecka, 2014, p. 173).

Although the main task of ECB is to maintain price stability, it undertook a series of actions, that should have restored financial stability in Europe.

Immediately after ECB has modified the maturity of open market operations and expanded the list of accepted collaterals, next step was establishment of swap lines with other central banks, whose task was to provide liquidity to commercial banks in foreign currencies. Scale and number of involved countries indicate the significance of anti-crisis tool. 
Purchase of debt securities (CBPP programs) was crucial for stabilizing actions in Europe. It improved banks' financing conditions and lending possibility by revitalizing debt security market. Program Securities Market Programme implemented buying government and private securities. Thanks to it, possibility of collapse of government bond market was abandoned in some euro area countries. It also contributed to improvement of monetary policy transmission mechanism. Unfortunately, the funds, raised by banks from this program, have been deposited in the accounts of ECB and therefore not spurred the real economy. With LTRO operations, main goals have been reached: it restored liquidity in banking sector and interest rates have been lowered. Banks, which were benefiting from preferential credits, invested this capital in bonds of European countries and thus contributed to lower their profitability.

Despite the lack of full implementation of OMT program, ECB's message about readiness to intervene, positively influenced interest rates of government bonds of countries facing debt crisis.

On conclusion, the actions undertaken by ECB as the unconventional monetary policy, can be evaluated as:

1) providing liquidity in the form of extended loan supply,

2) taking the form of direct purchase operations of government and private securities on the secondary market by ECB,

3) shaping long-term expectations through appropriate information policy (Żywiecka, 2014, p. 200).

Above mentioned activities were aimed at supporting the European banking sector. Therefore, buying assets programs were conducted on smaller scale and some of them contained assumption of sterilization transactions - it was afeature different from the traditional quantitative easing programs.

Although the article focused on the positive effects of ECB's unconventional policy, it is worth to notice that there has been a vivid discussion whether the scale, time and manner of changes in the monetary policy were effective in achieving the intended purposes. It has been argued that they could lead to lower effectiveness of the tools, including:

1) anchoring in the euro zone pessimistic expectations about the prospects for economic growth, as a result of sluggish, late and too weak anti-crisis measures used by ECB,

2) ECB has never defined desirable level of key real medium-term indicators, such as desired level of unemployment and economic growth, which would have helped to change the expectations, 
3) the inflation target was treated as the master parameter of ECB's monetary policy, which could mean too narrow margin for growth in nominal incomes, discouraging business entities to plan larger scale of production,

4) implemented programs of security purchases exerted only temporary effects on ECB's balance sheet and monetary base in the euro zone,

5) too early termination of quantitative easing programs could have negative impact on functioning of important sectors in the economic market,

6) there is potential risk of financial loss by the ECB, related to purchase of securities with poor quality.

However, given the fact, that the unconventional tools were used for the first time on such a big scale, it is difficult to predict their negative long-term effects (Bednarczyk, 2015, p. 97). Therefore, the overall assessment of steps undertaken by the European Central bank in years 2008-2012 should be positive. These actions have substantially increased liquidity in banking sector and contributed to avoidance of insolvency of euro area countries. Despite the fact that the unconventional monetary policy tools have often only mitigate the negative consequences, rather than removing the source of crisis, it should be stated that the European Central bank has significantly contributed to maintaining stability in European financial system.

\section{REFERENCES}

Bednarczyk, J.L. (2015). Polityka pieniężna Europejskiego Banku Centralnego a zagrożenie deflacją w Unii Europejskiej, http://kolegia.sgh.waw.pl/pl/KES/kwartalnik/ Documents/JB231.pdf (accessed: 10.10.2016).

Bernanke, B.S., Reinhart, V.R., Sack, B.P. (2004). Monetary Policy Alternatives at the Zero Bound: An Empirical Assessment. Finance and Economics Discussion Series, 48, Washington.

Bogołębska, J. (2012). Instrumenty polityki pieniężnej Europejskiego Banku Centralnego w okresie globalnego kryzysu finansowego. Acta Universitatis Lodziensis, no. 264.

Capiga, M., Gradoń, W., Szustak, G. (2010). Sieć bezpieczeństwa finansowego. Warszawa: CeDeWu.

Dobrzańska, A. (2014). Polityka makroostrożnościowa - zagadnienia instytucjonalne. Teoria i dotychczasowe doświadczenia w Unii Europejskiej. Materiały i Studia, no. 307, NBP, Warszawa.

Issing, O. (2014). Forward Guidance. A new challenge for central banks. SAFE White Paper Series, no. 16.

Janus, J. (2013). Niekonwencjonalna polityka pieniężna głównych banków centralnych - diagnoza korzyści i zagrożeń, IX Kongres Ekonomistów Polskich. 
Kałuzińska, V. (2009). Bank centralny wobec kwestii stabilności systemu finansowego. Ruch Prawniczy, Ekonomiczny i Socjologiczny, no. 1.

Kapuściński, M., Łyziak, T., Przystupa J., Stanisławska, E., Sznajderska, A., Wróbel, E. (2014). Mechanizm transmisji polityki pieniężnej w Polsce. Co wiemy w 2013 roku? Materiały i studia, no. 306, NBP.

Lenza, M., Pill, H., Reichlin, L. (2010). Monetary policy in exceptional times. Working Paper Series, no. 1253, EBC.

Myślak, E. (2013). Narodowy Bank Polski w systemie ustrojowym Rzeczpospolitej Polskiej. Kraków: Wydawnictwo Uniwersytetu Jagiellońskiego.

Niczy poruk, P., Talecka, A. (2010). Bankowość Unii Europejskiej. Białystok: Temida 2.

Pronobis, M. (2014). Rola polityki Europejskiego Banku Centralnego w zarzadzaniu antykryzysowym w Europie. Zeszyt naukowy, no. 58, Warszawa: Centrum Europejskie Natolin.

Przybylska- Kapuścińska, W. (2012). Problemy polityki pieniężnej banków centralnych w okresie kryzysu. Ekonomia i Prawo, 10(3).

Szczepańska, O. (2007). Rola banku centralnego w sieci bezpieczeństwa finansowego. Bezpieczny Bank, no. 2, BFG.

Szczepańska, O. (2008). Stabilność finansowa jako cel banku centralnego, studium teoretyczno-porównawcze. Warszawa: Wydawnictwo Naukowe Scholar.

Traktat o Funkcjonowaniu Unii Europejskiej, Dz. U .z 2012, poz.0001-0390.

Żywiecka, H. (2010). Stabilność finansowa jako cel współczesnego banku centralnego. Bezpieczny Bank, no. 3.

Żywiecka, H. (2014). Niestandardowe działania banków centralnych w warunkach globalnego kryzysu finansowego. Warszawa: CeDeWu.

http://www.ecb.europa.eu/mopo/pdf/150202_faq_CBPP3.pdf (2014) (accessed: 15.10. 2016).

http://www.ecb.europa.eu/pub/pdf/other/mb201201_focus04.en.pdf (2012) (accessed: 16.10.2016).

https://placeduluxembourg.wordpress.com/2012/02/22/ecb-market-intervention-covered-bond-purchasing-programme-cbpp/ (2012a) (accessed: 12.10.2016).

https://placeduluxembourg.wordpress.com/2012/03/02/ecb-market-intervention-thesecurities-market-programme-smp/(2012b) (accessed: 12.10.2016).

https://www.ecb.europa.eu/ecb/tasks/stability/html/index.pl.html (2016b) (accessed: 20.09.2016).

https://www.ecb.europa.eu/press/pr/date/2011/html/pr111103_1.en.html. (2011b) (accessed: 14.10 .2016$)$.

https://www.ecb.europa.eu/press/pressconf/2008/html/is080703.en.html (2008) (accessed: 05.10.2016).

https://www.ecb.europa.eu/press/pressconf/2011/html/is110407.en.html (2011a) (accessed: 05.10.2016).

www.bis.org/review/r080610a.pdf (2008) (accessed: 26.09.2016).

www.ecb.europa.eu/stats/monetary/rates/html/index.en.html (2016a) (accessed: 28.09. 2016). 